\title{
Pelatihan Swamedikasi Dalam Rumah Tangga Di Kelurahan Tarantang
}

\author{
Rika Sepriani \\ Jurusan Pendidikan Olahraga, Fakultas Ilmu Keolahragaan, Universitas Negeri Padang

\section{Email: rikasepriani@fik.unp.ac.id ${ }^{1}$}

\begin{abstract}
Health is a healthy state, both physically, mentally, spiritually and socially that allows everyone to live productively socially and economically. Health development as one of the national developments designed for the achievement of awareness, willingness and ability to live healthy for every population to realize an optimal degree of public health. Self-medication is an attempt by someone to overcome a problem of illness or disease without prior agreement with a doctor or health worker. More than $60 \%$ of members of the public swarmed the legal basis Permenkes No.919 / MENKES / PER / X / 1993. Swamedication was more focused on handling quickly and effectively without prior intervention by medical consultants, pharmacists, to reduce the workload on the limited resources and labor. The target audience for this community service activity is $\mathbf{3 0}$ health cadres obtained through collaboration with the state visited by the health cadres to provide information and understanding to other community members in their neighborhoods. From this dedication activity obtained 1) Increased knowledge and understanding of health cadres about selfmedication 2) Increased knowledge and understanding of health cadres about managing drugs in the household.
\end{abstract}

Keywords: self-authentication, tarantang

\section{Abstrak}

Kesehatan adalah keadaan sehat, baik secara fisik, mental, spiritual maupun sosial yang memungkinkan setiap orang hidup produktif secara sosial dan ekonomis. Pembangunan kesehatan sebagai salah satu upaya pembangunan nasional diarahkan guna tercapainya kesadaran, kemauan dan kemampuan untuk hidup sehat bagi setiap penduduk agar terwujud derajat kesehatan masyarakat yang optimal. Swamedikasi adalah upaya seseorang dalam mengobati gejala sakit atau penyakit tanpa berkonsultasi dengan dokter atau tenaga kesehatan terlebih dahulu. Lebih dari $60 \%$ dari anggota masyarakat melakukan swamedikasi dengan dasar hukum Permenkes No.919/MENKES/PER/X/1993. Swamedikasi lebih terfokus pada penanganan terhadap gejala secara cepat dan efektif tanpa intervensi sebelumnya oleh konsultan medis kecuali apoteker, sehingga dapat mengurangi beban kerja pada kondisi terbatasnya sumber daya dan tenaga. Khalayak sasaran kegiatan pengabdian ini adalah kader kesehatan sebanyak 30 orang yang didapatkan melalui kerjasama dengan kelurahan yang nantinya para kader kesehatan ini dapat memberikan informasi dan pemahaman kepada anggota masyarakat yang lain yang ada di lingkungan tempat tinggalnya. Dari kegiatan pengabdian ini didapatkan 1) Peningkatan pengetahuan dan pemahaman para kader kesehatan tentang swamedikasi 2) Peningkatan pengetahuan dan pemahaman para kader kesehatan tentang pengelolaan obat di rumah tangga.

Kata kunci: swamedikasi, tarantang

\section{ANALISIS SITUASI}

Kualitas sumber daya manusia yang memadai dipengaruhi salah satunya oleh tingkat kesehatan penduduk. Agar kondisi kesehatan penduduk tetap sehat, maka 
penyediaan sarana kesehatan dan tenaga kesehatan harus memadai, baik kuantitas maupun kualitasnya. Di Kecamatan Lubuk Kilangan terdapat satu unit Puskesmas yang terletak di kelurahan Bandar Buat sedangkan untuk kelurahan lainnya terdapat satu unit Puskesmas Pembantu namun pada kelurahan Tarantang tidak memiliki Puskesmas Pembantu.

Kelurahan Tarantang merupakan salah satu kelurahan di kecamatan Lubuk Kilangan yang memiliki luas $1.85 \mathrm{~km}^{2}$. Berdasarkan data stistik tahun 2012 kelurahan Tarantang memiliki jumlah penduduk 2.335 dari 534 kepala keluarga (KK) yang terdiri atas 1.148 laki-laki dan 1.187 perempuan (Bapedda, 2012). Kelurahan Tarantang tidak memiliki fasilitas pelayanan kesehatan seperti puskesmas, apotik, klinik ataupun puskesmas pembantu yang seharusnya dengan jumlah penduduk yang cukup banyak kelurahan Tarantang sebaiknya memiliki fasilitas kesehatan. Berdasarkan observasi yang dilakukan, akses masyarakat kelurahan Tarantangpun ke pusat pelayanan kesehatan kecamatan hanya dapat dilakukan dengan menggunkan kendaraan sendiri atau menggunakan ojek karena tidak adanya angkutan umum (angkot).

Swamedikasi, atau pengobatan sendiri adalah perilaku untuk mengatasi sakit ringan sebelum mencari pertolongan ke petugas atau fasilitas kesehatan. Lebih dari $60 \%$ dari anggota masyarakat melakukan swamedikasi dengan dasar hukum permenkes No.919/MENKES/PER/X/1993. Secara sederhana swamedikasi adalah upaya seseorang dalam mengobati gejala sakit atau penyakit tanpa berkonsultasi dengan dokter terlebih dahulu.

Keuntungan pengobatan sendiri adalah aman apabila digunakan sesuai dengan petunjuk, efek samping dapat diperkirakan, efektif untuk menghilangkan keluhan karena $80 \%$ sakit bersifat self limiting, yaitu sembuh sendiri tanpa intervensi tenaga kesehatan, biaya pembelian obat relatif lebih murah daripada biaya pelayanan kesehatan, hemat waktu karena tidak perlu mengunjungi fasilitas profesi kesehatan, kepuasan karena ikut berperan aktif dalam pengambilan keputusan terapi, berperan serta dalatn sistem pelayanan kesehatan, menghindari rasa malu atau stres apabila harus menampakkan 
bagian tubuh tertentu di depan tenaga kesehatan, dan membantu pemerintah mengatasi keterbatasan jumlah tenaga kesehatan di masyarakat.

Swamedikasi sebenarnya merupakan bantuan yang sangat besar bagi pemerintah dalam hal pemerintahan kesehatan secara nasional apabila dilakukan dengan benar. Untuk melakukan pengobatan sendiri secara benar, masyarakat memerlukan informasi yang jelas dan dapat dipercaya, agar penentuan kebutuhan jenis/jumlah obat dapat diambil berdasarkan alasan yang rasional.

Secara lebih rinci selain mengetahui gejala sakit agar dapat mendiagnosis penyakitnya, pelaku pengobatan sendiri harus mampu: 1) mengetahui jenis obat yang diperlukan untuk mengatasi penyakitnya, sehingga dapat memilih secara tepat dari berbagai merek dagang obat yang tersedia, 2) mengetahui kegunaan dari tiap obat, sehingga dapat mengevaluasi sendiri pengembangan sakitnya, 3) menggunakan obat tersebut secara benar (cara, aturan, lama, pemakaian) dan tahu batas kapan mereka harus menghentikan swamedikasi dan segera minta pertolongan petugas kesehatan, 4) mengetahui efek samping sehingga dapat memperkirakan apakah suatu keluhan yang timbul kemudian itu suatu penyakit baru atau efek samping obat, 5) mengetahui siapa yang tidak boleh menggunakan obat tersebut (kontraindikasi). Sayangnya, pengetahuan inilah yang jarang dikuasai masyarakat. Beberapa penelitian menunjukkan bahwa dari skor maksimal (10), skor rata-rata yang umumnya dicapai oleh pelaku swamedikasi berkisar antara 3,5-5,5.

Pelaku swamedikasi sangat sedikit yang mengetahui kandungan obat yang diminum, lebih sedikit lagi jumlah yang mengetahui efek samping dan kontraindikasi obat tersebut. Informasi mengenai obat umumnya telah tersedia dalam kemasan obat, namun informasi ini sedikit dimanfaatkan oleh karena salah satunya gencarnya iklan obat yang menampilkan informasi minimal mengenai obat dan bahan aktif yang terkandung di dalamnya, sehingga masyarakat kehilangan satu titik informasi yang penting yaitu jenis obat yang dibutuhkan untuk mengatasi gejala sakitnya.

Sering dijumpai pemakaian beberapa nama dagang obat yang isinya persis sama. Selain dari segi ekonomi merupakan suatu pemborosan dan dapat berisiko terhadap 
kesehatan karena pemakaian obat yang salah dalam waktu yang lama, dan risiko karena kontraindikasi. Dengan melihat aspek kebutuhan informasi untuk meningkatkan kualitas swamedikasi maka diperlukan upaya untuk membekali masyarakat agar mempunyai keterampilan mencari informasi secara cepat dan benar, dengan memanfaatkan sumbersumber informasi yang telah tersedia di masyarakat.

Berdasarkan hal tersebut diatas maka perlu dilakukannya pemberian pengetahuan dan informasi kepada masyarakat di kelurahan Tarantang tentang swamedikasi (pengobatan sendiri) sehingga dengan keterbatasan fasilitas dan tenaga kesehatan tersebut masyarakat mampu untuk melalukan pengobatan terhadap dirinya sendiri, anggota keluarga ataupun masyarakat dilingkungannnya dengan tepat dan efektif sehingga peningkatan derajat kesehatan masyarakat dalam pelaksanaan misi pembangunan kesehatan dapat tercapai.

\section{SOLUSI DAN TARGET LUARAN}

Untuk mengatasi kurangnya pengetahuan masyarakat di kelurahan Tarantang tentang swamedikasi dan penggunaan obat dalam rumah tangga maka solusi yang ditawarkan:

1. Memberikan informasi dan pengetahuan tentang swamedikasi secara tepat dan benar

2. Memberikan informasi dan pengetahuan tentang penggunaan obat dalam rumah tangga

\section{Target Luaran}

Target luaran dari kegiatan ini adalah:

1. Peningkatan pengetahuan dan pemahaman masyarakat tentang swamedikasi secara tepat dan benar

2. Kegiatan pengabdian kepada masyarakat ini akan dipublikasikan dalam jurnal nasional ber-ISSN. 


\section{METODE PELAKSANAAN}

\section{Tempat dan Waktu}

Kegiatan ini pengabdian kepada masyarakat ini telah dilaksanakan di Kelurahan Tarantang selama dua hari, mulai tanggal 25 s/d 26 November 2015

\section{Khalayak Sasaran.}

Sasaran dalam kegiatan pengabdian ini adalah para kader kesehatan sebanyak 30 orang yang didapatkan melalui kerjasama dengan kelurahan Tarantang kecamatan Lubuk Kilangan kota Padang yang nantinya para kader kesehatan ini dapat memberikan informasi dan pemahaman kepada anggota masyarakat yang lain yang ada di lingkungan tempat tinggalnya.

\section{Metode Pengabdian}

Sesuai dengan tujuan yang ingin dicapai, maka metode kegiatan yang akan diterapkan adalah:

1. Metode ceramah dalam penyampaian materi swamedikasi dan pengelolaan obat rumah tangga.

2. Metode demonstrasi untuk melakukan swamedikasi dan pengelolaan obat di rumah tangga.

3. Melakukan diskusi yang berkaitan dengan materi swamedikasi dan pengelolaan obat rumah tangga.

\section{PELAKSANAAN KEGIATAN}

Sebelum kegiatan pengabdian dilaksanakan, tim pengabdian melakukan proses sosialisasi terlebih dahulu kepada khalayak sasaran. Tim pengabdian mengundang para kader kesehatan yang difasilitasi oleh kelurahan tarantang untuk berkomunikasi dan menjelaskan tujuan dan pentingnya kegiatan pengabdian ini dilaksanakan. Kegiatan pengabdian ini dilakukan melalui: 
1. Pemberian materi

Pemberian materi dilakukan melalui metode ceramah kepada khalayak sasaran tentang bagaimana cara melakukan swamedikasi secara tepat dan benar. Materi yang diberikan memuat informasi tentang:

a. Penyakit apa saja yang boleh dilakukan swamedikasi

b. Penggunaan obat secara tepat dan benar dalam melakukan swamedikasi

c. Cara penggunaan obat yang tepat dalam swamedikasi

d. Dosis obat yang tepat dalam swamedikasi

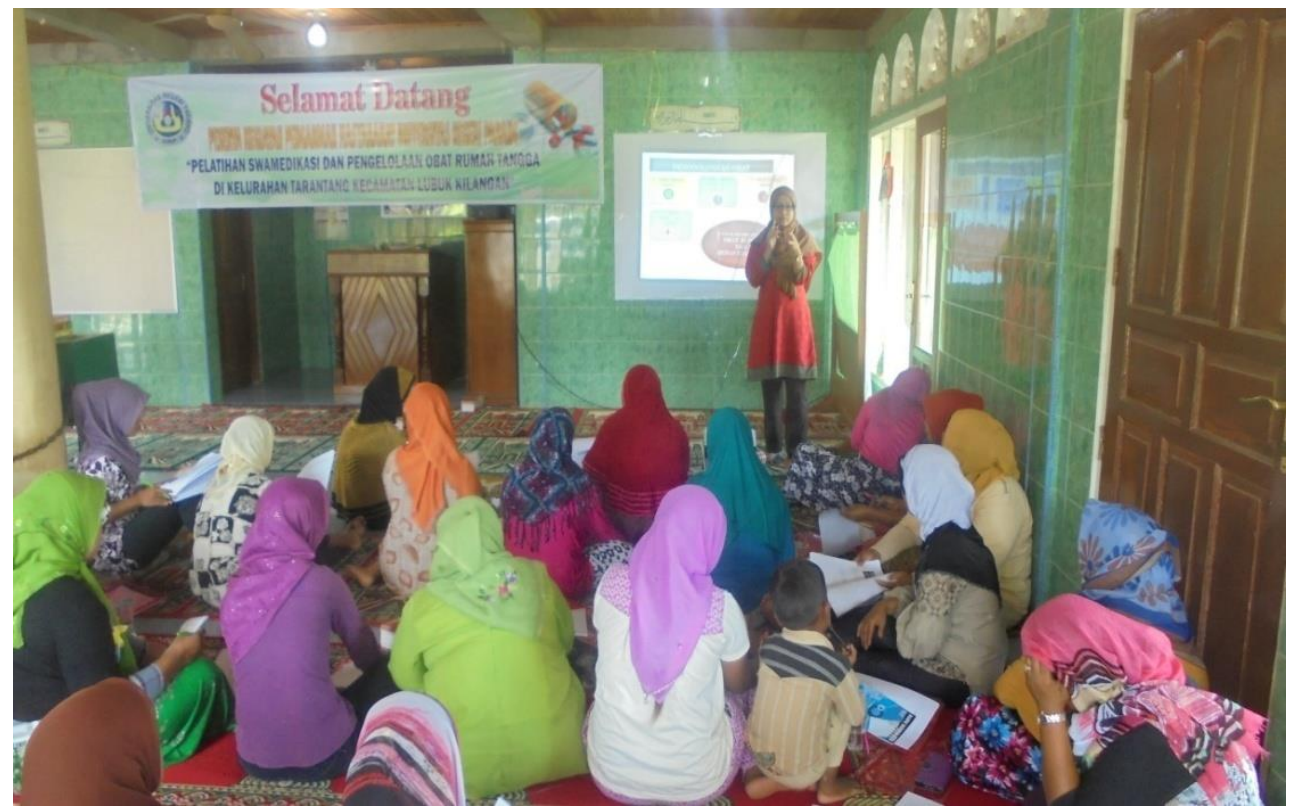

2. Melakukan diskusi tentang pelaksanaan swamedikasi

Diskusi ini dilakukan agar khalayak sasaran lebih memahami tentang swamedikasi secara tepat dan benar. Khalayak sasaran sangat antusias dalam kegiatan diskusi ini karena mereka memiliki rasa ingin tahu yang besar tentang bagaimana melakukan swamedikasi. Swamedikasi ini mampu membantu mereka dalam mengatasi gangguan kesehatan yang dialami dengan keterbatasan fasilitas kesehatan di daerah mereka. 
JURNAL BERKARYA PENGABDIAN PADA MASYALTAKATJ

Volume 1, No.1, 2019

ISSN — (Print) I

Open Access | http:jba.ppj.unp.acild
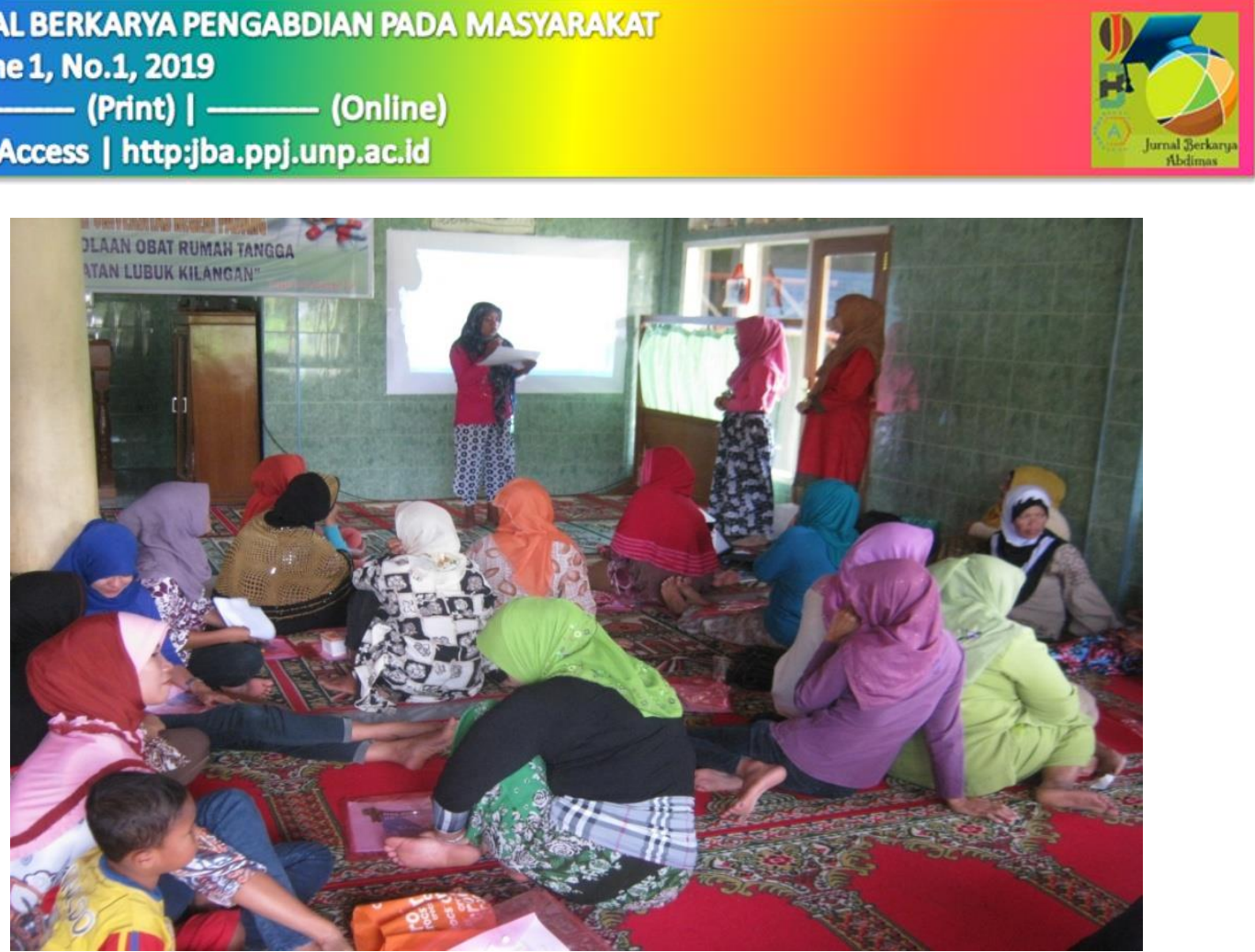

3. Melakukan pelatihan swamedikasi

Pelatihan swamedikasi ini dilakukan melalui pemberian contoh kasus kepada khalayak sasaran sehingga mereka dapat lebih memahami tentang bagaimana melakukan swamedikasi secara tepat dan benar sehingga nantinya mereka mampu melakukannya sendiri, baik dalam melakukan pengobatan terhadap diri sendiri, keluarga ataupun masyarakat sekitar.

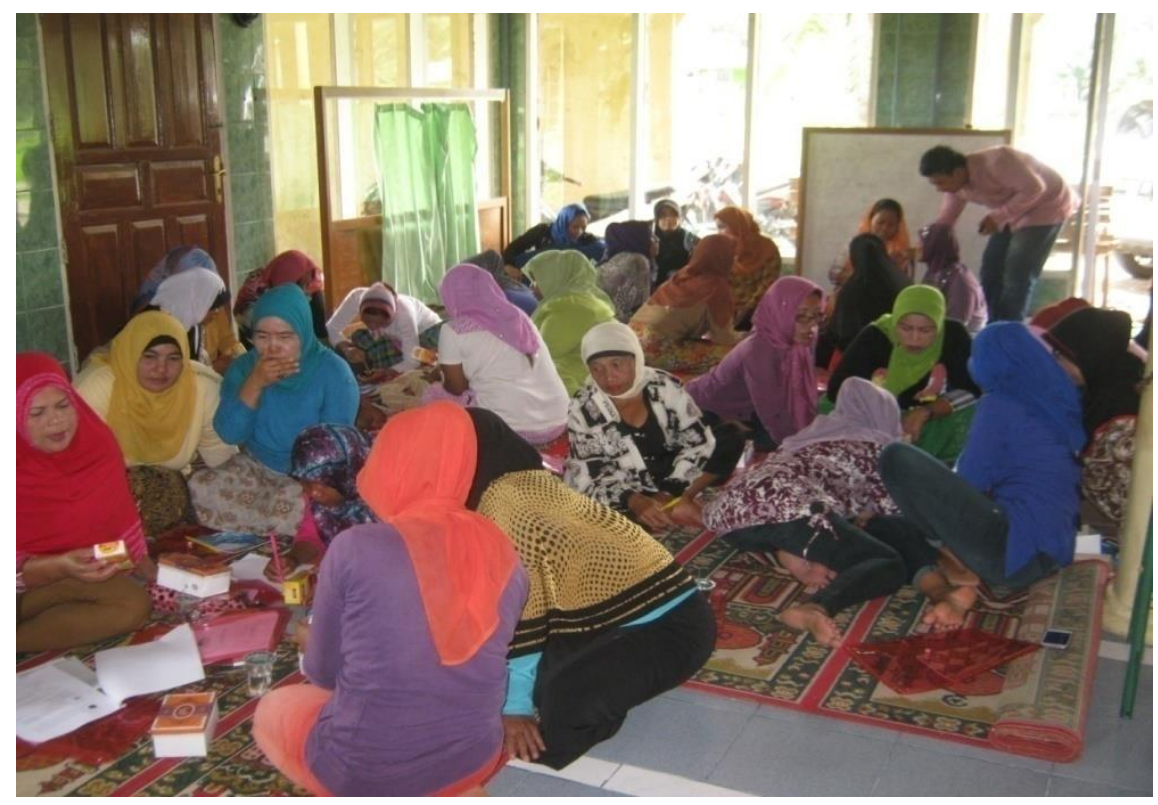




\section{HASIL DAN PEMBAHASAN}

\section{Hasil}

Berdasarkan pelaksanaan kegiatan pengabdian dapat diperoleh hasil sebagai berikut:

1. Peningkatan pengetahuan dan pemahaman para kader kesehatan tentang swamedikasi

2. Peningkatan pengetahuan dan pemahaman tentang tata kelola obat di rumah tangga

\section{Pembahasan}

\section{Peningkatan Pengetahuan dan Pemahaman para Kader Kesehatan Tentang Swamedikasi}

Kegiatan pelatihan ini diikuti oleh 30 peserta yakni kader kesehatan dari kelurahan Tarantang kecamatan Lubuk Kilangan. Acara diawali dengan perkenalan dari tim Kesehatan Universitas Negeri Padang dan menjelaskan tujuan dari pelatihan ini. Kemudian kami membagikan lembaran pre-test untuk mengetahui seberapa jauh pengetahuan peserta mengenai swamedikasi dan tata kelola obat di rumah tangga. Peserta diberi waktu 15 menit untuk mengisi lembaran pre-test. Setelah diisi, lembaran pre-test kemudian dikumpulkan dan dilanjutkan dengan penyampaian materi.

Dari pretest yang dilakukan yang berkaitan dengan pelaksanaan swamedikasi rata-rata peserta hanya mampu menjawab 2 dari 5 buah pertanyaan yang diberikan (40\%). Hal ini dapat disebabkan karena beberapa hal seperti faktor pendidikan, ekonomi dan kurangnya informasi dari petugas kesehatan. Dari data yang diperoleh, rata-rata kader kesehatan yang ikut dalam pelatihan swamedikasi dan pengelolaan obat rumah tangga di Kelurahan Tarantang Kecamatan Lubuk Kilangan memiliki tingkat pendididkan SMP dan SMA dengan pekerjaan sebagai Ibu Rumah Tangga dan pekerjaan suami yang pada umumnya sebagai buruh.

Banyak faktor yang berhubungan dengan perilaku penggunaan obat dalam pengobatan sendiri. Supardi menyatakan bahwa belum diketahui faktor yang paling berpengaruh dalam perilaku pengobatan sendiri. Namun demikian berdasarkan penelitian 
Kristina dkk., faktor yang paling berpengaruh dalam perilaku pengobatan sendiri adalah tingkat pendidikan.

Semakin tinggi pendidikan, pengobatan yang dilakukan juga semakin rasional. Kekuatan hubungan jika diurutkan mulai dari yang terkuat kemudian semakin lemah adalah variabel pendidikan, sikap, status pekerjaan, jenis kelamin dan yang terakhir pengetahuan tentang pengobatan sendiri. Menurut Worku dan Abebe, berdasarkan faktor sosiodemografi seperti umur, jenis kelamin, dan pendapatan, yang paling banyak melakukan pengobatan sendiri adalah kelompok usia di bawah 30 tahun 59,5\%, jenis kelamin perempuan 61,9\%, dan kelompok berpenghasilan tinggi 40,5\% (Susi, dkk., 2008).

Dalam pelaksanaan pelatihan ini awalnya peserta masih bingung terhadap materi yang kami berikan. Namun setelah kami menjelaskan lebih lanjut dan memaparkan beberapa teori akhirnya peserta mulai mengerti dan nampak antusias dalam mengikuti kegiatan tersebut. Situasi selama penyuluhan sangatlah kondusif, hal ini dikarenakan peserta aktif dalam berdiskusi dalam kelompok maupun terhadap kelompok lain sehingga tercipta suasana yang nyaman dalam berdiskusi.

Pada akhir kegiatan pelatihan, kami melakukan posttest kepada peserta untuk melihat bagaimana tingkat pemahaman mereka tentang materi yang diberikan. Soal yang diberikan sama dengan soal pretest yang telah diberikan sebelumnya. Dari hasil yang di dapatkan rata-rata peserta mampu menjawab 4 dari 5 pertanyaan yang diberikan $(80 \%)$ berkaitan dengan swamedikasi.

Tujuan pengobatan sendiri adalah untuk peningkatan, pengobatan sakit ringan, dan pengobatan rutin penyakit kronis setelah perawatan dokter. Sementara itu, peran pengobatan sendiri adalah untuk menanggulangi secara cepat dan efektif keluhan yang tidak memerlukan konsultasi medis, mengurangi beban pelayanan kesehatan pada keterbatasan sumber daya dan tenaga, serta meningkatkan keterjangkauan masyarakat yang jauh dari pelayanan kesehatan (Supardi, 1997).

Keuntungan pengobatan sendiri adalah aman apabila digunakan sesuai dengan petunjuk, efek samping dapat diperkirakan, efektif untuk menghilangkan keluhan karena 
$80 \%$ sakit bersifat self limiting, yaitu sembuh sendiri tanpa intervensi tenaga kesehatan, biaya pembelian obat relatif lebih murah daripada biaya pelayanan kesehatan, hemat waktu karena tidak perlu mengunjungi fasilitas profesi kesehatan, kepuasan karena ikut berperan aktif dalam pengambilan keputusan terapi, berperan serta dalatn sistem pelayanan kesehatan, menghindari rasa malu atau stres apabila harus menampakkan bagian tubuh tertentu di depan tenaga kesehatan, dan membantu pemerintah mengatasi keterbatasan jumlah tenaga kesehatan di masyarakat (Supardi, 1997).

Kelurahan Tarantang tidak memiliki fasilitas pelayanan kesehatan seperti puskesmas, apotik, klinik ataupun puskesmas pembantu yang seharusnya dengan jumlah penduduk yang cukup banyak kelurahan Tarantang sebaiknya memiliki fasilitas kesehatan. Oleh sebab itu dengan adanya pelatihan swamedikasi dan pengelolaan obat rumah tangga para kader kesehatan yang ada di kelurahan Tarantang mampu untuk melakukan swamedikasi secara tepat dan benar sekaligus memberikan informasi kepada tetangga dan masyarakat yang ada di lingkungannya sehingga dapat meningkatkan derajat kesehatan dan mengurangi biaya dan pengeluaran rumah tangga yang berkaitan dengan kesehatan.

\section{Peningkatan Pengetahuan dan Pemahaman Tentang Tata Kelola Obat di Rumah Tangga}

Obat merupakan substansi apapun yang efek kimianya dapat mengubah fungsi biologis. Swamedikasi harus dilakukan sesuai dengan penyakit yang dialami. Pelaksanaannya sedapat mungkin harus memenuhi kriteria penggunaan obat yang rasional, antara lain ketepatan pemilihan obat, ketepatan dosis obat, tidak adanya efek samping, tidak adanya kontraindikasi, tidak adanya interaksi obat, dan tidak adanya polifarmasi (Kristina, dkk 2008 didalam Prameshwari, 2009).

Untuk mengetahui pengetahuan masyarakat Kelurahan Tarantang Kecamatan Lubuk Kilangan mengenai tata kelola obat di rumah tangga yang berkaitan erat dengan praktek swamedikasi, kami melakukan pretest ke pada peserta dengan memberikan 5 buah pertanyaan. Dari hasil pretest di dapatkan dari 5 buah pertanyaan rata-rata peserta 
mampu menjawab benar 1 buah pertanyaan (20\%). Dimana hal ini menunjukkan bahwa masih kurangnya pengetahuan peserta tentang tata kelola obat di rumah tangga. Jika masyarakat tidak memiliki pengetahuan yang cukup tentang tata kelola dan penggunaan obat maka tentunya ini akan menambah resiko kesehatan pada masyarakat.

Untuk melakukan pengobatan sendiri secara benar, masyarakat harus mampu:

1. Mengetahui jenis obat yang diperlukan untuk mengatasi penyakitnya.

2. Mengetahui kegunaan dari tiap obat, sehingga dapat mengevaluasi sendiri perkembangan sakitnya.

3. Menggunakan obat tersebut secara benar (cara, aturan, lama pemakaian) dan tahu batas kapan mereka harus menghentikan self medication dan segera minta pertolongan petugas kesehatan.

4. Mengetahui efek samping obat yang digunakan sehingga dapat memperkirakan apakah suatu keluhan yang timbul kemudian itu suatu penyakit baru atau efek samping obat.

5. Mengetahui siapa yang tidak boleh menggunakan obat tersebut (Depkes-RI, 2008).

Masalah dalam penggunaan obat pada pengobatan sendiri antara lain meliputi penggunaan obat yang tidak tepat, tidak efektif, tidak aman, dan juga tidak ekonomis.

Menurut Supardi dan Notosiswoyo pengetahuan pengobatan sendiri umumnya masih rendah dan kesadaran masyarakat untuk membaca label pada kemasan obat juga masih kecil (Supardi, 1997). Sumber informasi utama untuk melakukan pengobatan sendiri umumnya berasal dari media massa. Secara umum, promosi obat yang ditampilkan di media saat ini sudah sangat berlebihan dan tidak objektif lagi. Jika hal ini tidak diimbangi dengan informasi obat yang benar, maka akan menjerumuskan masyarakat ke arah penggunaan obat yang tidak rasional. Menurut Suryawati, informasi dari pabrik obat ada yang kurang mendidik masyarakat, bahkan ada yang kurang benar (Susi, dkk., 2008).

Tata kelola obat di rumah tangga berkaitan dengan penggolongan obat, penyimpanan, ciri-ciri obat rusak, kadaluarsa obat, cara penggunaan obat, efek samping 
obat dan dosis obat. Masalah dalam penggunaan obat pada swamedikasi antara lain meliputi penggunaan obat yang tidak tepat, tidak efektif, tidak aman, dan juga tidak ekonomis. Masalah tersebut biasanya dikenal dengan istilah penggunaan obat yang tidak rasional. Pengobatan dikatakan tidak rasional jika (Depkes, 2008) :

a. Pemilihan obat tidak tepat, maksudnya obat yang dipilih bukan obat yang terbukti paling bermanfaat, paling aman, paling sesuai dan paling ekonomis.

b. Penggunaan obat yang tidak tepat, yaitu tidak tepat dosis, tidak tepat cara pemberian obat, dan tidak tepat frekuensi pemberian.

c. Pemberian obat tidak disertai dengan penjelasan yang sesuai, kepada pasien atau keluarga.

d. Pengaruh pemberian obat, baik yang diinginkan atau tidak diinginkan tidak diperkirakan sebelumnya dan tidak dilakukan pemantauan secara langsung atau tidak langsung.

e. Penggunaan obat dikatakan tidak tepat jika risiko yang mungkin terjadi tidak seimbang dengan manfaat yang diperoleh dari tindakan pemberian suatu obat.

Dalam pelaksanaan pelatihan ini awalnya peserta masih bingung terhadap materi yang diberikan karena banyaknya istilah yang terdengar asing bagi merekaa. Namun setelah kami menjelaskan lebih lanjut dan memaparkan beberapa teori akhirnya peserta mulai mengerti dan nampak antusias dalam mengikuti kegiatan tersebut.

Pada akhir kegiatan pelatihan, kami melakukan posttest kepada peserta untuk melihat bagaimana tingkat pemahaman mereka tentang materi yang diberikan. Soal yang diberikan sama dengan soal pretest yang telah diberikan sebelumnya. Dari hasil yang di dapatkan rata-rata peserta mampu menjawab 4 dari 5 pertanyaan yang diberikan $(80 \%)$ yang berkaitan dengan tata kelola obat di rumah tangga. Dengan adanya pelatihan ini para kader kesehatan mampu untuk melakukan penggunaan obat secara rasional bagi sendiri, anggota keluarga dan masyarakat sekitar. 


\section{KESIMPULAN}

Berdasarkan pengabdian kepada masyarakat yang telah dilakukan dengan judul pelatihan swamedikasi dan pengelolaan obat rumah tangga di kelurahan Tarantang kecamatan Lubuk Kilangan dapat ditarik kesimpulan yaitu:

1. Terjadinya peningkatan pengetahuan dan pemahaman para kader kesehatan tentang swamedikasi dan apa saja hal yang harus diperhatikan dalam pelaksanaan swamedikasi dan kondisi atau keadaan yang dapat diterapi secara swamedikasi..

2. Terjadinya peningkatan pengetahuan dan pemahaman tentang tata kelola obat di rumah tangga berkaitan dengan penggolongan obat, penyimpanan, ciri-ciri obat rusak, kadaluarsa obat, cara penggunaan obat, efek samping obat dan dosis obat.

\section{DAFTAR PUSTAKA}

Badan Perencanaan Pembangunan Daerah Kota Padang. 2013. Lubuk Kilangan dalam Angka 2012. Bapeda: Padang.

Departemen Kesehatan Indonesia. 2008. Materi Pelatihan Peningkatan Pengetahuan dan Keterampilan Memilih Obat bagi Tenaga Kesehatan. direktorat Bina Farmasi Komunitas dan Klinik Ditjen Bina Kefarmasian dan Alat Kesehatan Departemen Kesehatan Republik Indonesia: Jakarta.

Kristina, SA., Prabandari, YS. dan Sudjaswadi, R. 2008. Perilaku Pengobatan Sendiri yang Rasional pada Masyarakat Kecamatan Depok dan Cangkringan Kabupaten Sleman (online), (diakses 20 Oktober 2016).

Supardi S. 1997. Pengobatan Sendiri di Masyarakat dan Masalahnya. Jakarta: Pusat Penelitian dan pengembangan Farmasi Badan Penelitian dan Pengembangan Kesehatan Departemen Kesehatan RI.

Susi AK., Yayi SP., Riswaka S. 2008. Perilaku Pengobatan Sendiri yang Rasional pada Masyarakat Kecamatan Depok dan Cangkringan Kabupaten Sleman. Majalah Farmasi Indonesia. 